Ambiente \& Água - An Interdisciplinary Journal of Applied Science
ISSN 1980-993X - doi:10.4136/1980-993X
www.ambi-agua.net
E-mail: ambi.agua@gmail.com

\title{
Chemical analysis of rainfall and throughfall in the Tapajós National Forest, Belterra, Pará, Brazil
}

\author{
doi: 10.4136/ambi-agua.1552
}

Received: 28 Oct. 2014; Accepted: 05 Feb. 2015

\author{
Raimundo Cosme de Oliveira Junior ${ }^{1 *}$; Michael Meier Keller²; \\ José Francisco da Fonseca Ramos ${ }^{3}$; Troy Patrick Beldini ${ }^{4}$; \\ Patrick Michael Crill ${ }^{5}$; Plinio Batista de Camargo ${ }^{6}$; Joost van Haren ${ }^{7}$

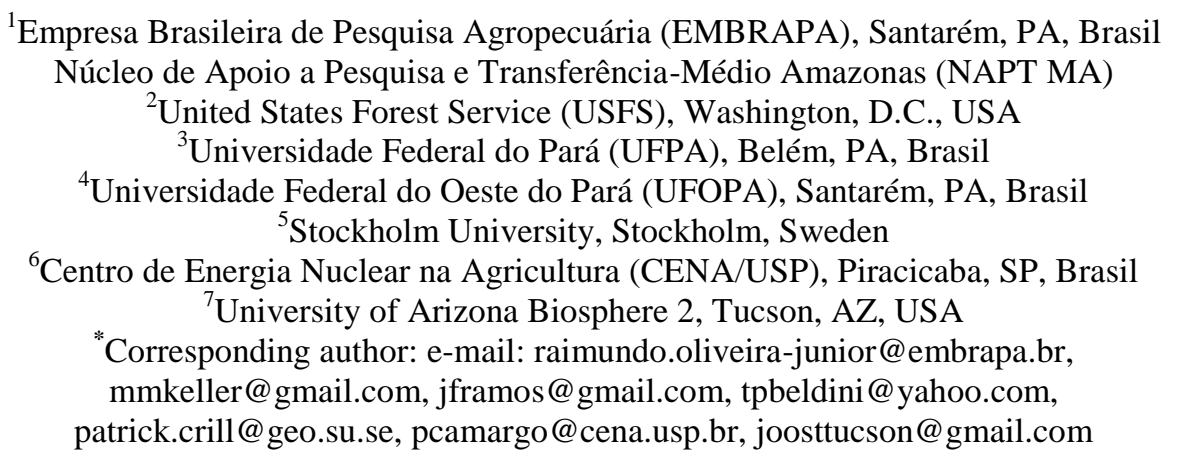

\section{ABSTRACT}

The Tapajós National Forest (FLONA Tapajós) has 600,000 hectares of protected forest, and is situated $50 \mathrm{~km}$ south of the city of Santarém, Pará, Brazil, a port city of 250,000 inhabitants that is located at the confluence of the Tapajós and Amazon Rivers. There is a lot of farmland in the region, which offers many opportunities to study changes in land use. Selective wood harvesting is one type of land use that is particularly important to the economy of Santarém. Wet and dry deposition of organic material can be an important source of nutrients for plants, and this is especially true when the soil is poor, which is the case in Santarem-Belterra plateau region, the study area of this research. In this region, the natural atmospheric deposition of nutrients is often enhanced by the burning of biomass, which releases a large part of the above-ground biomass nutrients into the atmosphere. The objectives of this study were: 1 - estimate the total wet deposition via direct precipitation and through the canopy, including dry deposition; 2 - verify potential sources of nutrients found in the total wet deposition and dry deposition; and 3 - investigate the effects of coverage vegetation on nutrient content in precipitation and throughfall. The study was conducted in FLONA Tapajós at km 67 of Santarém- Cuiabá Highway, south of the city of Santarém. The study area consisted of a portion of $100 \times 100 \mathrm{~m}$ transects divided into $10 \times 10 \mathrm{~m}$ plots. The area was located next to a meteorological tower $65 \mathrm{~m}$ tall that measures various climate parameters such as rainfall, wind speed and direction, solar radiation, temperature and humidity, among others. Direct precipitation (PD) and internal precipitation (IP) collectors consisted of $2 \mathrm{~L}$ polyethylene bottles with a $115 \mathrm{~mm}$ diameter funnel. Samples were collected weekly from April 2003 to March 2006. The volume of the sample was measured individually for each collector (25 traps for internal precipitation and 4 for direct precipitation). The conclusions that can be drawn from this study are: 1 - the dry season has the highest variation 
in ion flux; 2 - seasonality has a strong influence on the concentration of basic cations; 3 - dry deposition is one of the most important ways that nutrients are acquired in FLONA Tapajos; 4 - there is a significant inflow of nutrients $\mathrm{Cl}$ and $\mathrm{Na}$ due to intensive grain farming nearby; 5 - dry deposition is the most important process for the enrichment of water that reaches the forest floor; 6 - principal component analysis facilitates the interpretation and characterization of rainwater and in this study shows the influence of anthropogenic sources such as agriculture, biomass burning, and dust.

Keywords: Amazon region, nutrient cycling, tropical forest.

\section{Análise química da água de chuva incidente e interceptada na Floresta Nacional do Tapajós, Belterra, Pará, Brasil}

\section{RESUMO}

A Floresta Nacional do Tapajós (FLONA Tapajós) possui 600 mil hectares de floresta protegida, e está situada a $50 \mathrm{~km}$ ao sul da cidade de Santarém, Pará, Brasil, uma cidade portuária de 250 mil habitantes, localizada na confluência dos rios Tapajós e Amazonas. Há abundância de terras agrícolas na região, que oferecem muitas oportunidades para estudar mudanças no uso da terra, e um tipo de uso da terra, a colheita seletiva de madeira, é particularmente importante para a economia de Santarém. A deposição úmida e seca pode ser uma importante fonte de nutrientes para as plantas, e isto é especialmente verdade quando os solos são pobres, o que é o caso na região do planalto Santarém-Belterra, a área de estudo da presente investigação. Nesta região, a deposição de nutrientes atmosférico natural é reforçada pela frequente queima de biomassa que libera uma grande parte dos nutrientes da biomassa acima do solo para a atmosfera. Os objetivos deste estudo foram: 1) Estimar a deposição úmida total via precipitação direta e através da copa, incluindo a deposição seca; 2) Verificar potenciais fontes de nutrientes encontrados na deposição úmida total e deposição seca; e, 3) Verificar possíveis efeitos da cobertura vegetal no teor de nutrientes na precipitação e precipitação interna. Este estudo foi realizado na FLONA Tapajós no km 67 da rodovia Santarém - Cuiabá, ao sul da cidade de Santarém. A área de estudo consistiu de uma parcela de $100 \times 100 \mathrm{~m}$ dividida em transectos de $10 \times 10 \mathrm{~m}$ que foi localizada próximo de uma torre meteorológica de $65 \mathrm{~m}$ que com medidas de vários parâmetros climáticos, como precipitação, velocidade e direção do vento, radiação solar incidente e temperatura e umidade do ar, entre outros. Coletores de precipitação direta (PD) e de precipitação interna (PI) consistiram de frascos de $2 \mathrm{~L}$ de polietileno com um funil de diâmetro de $115 \mathrm{~mm}$. As amostras foram coletadas semanalmente durante abril de 2003 a março de 2006. O volume da amostra foi medido individualmente para cada coletor ( 25 coletores para a precipitação interna e 4 para a precipitação direta). As conclusões que podem ser tiradas a partir deste estudo são: 1) A estação seca apresenta a maior variação no fluxo de íons; 2) A sazonalidade exerce uma forte influência sobre a concentração de cátions básicos; 3) A deposição seca é um das mais importantes caminhos para a entrada de nutrientes na FLONA Tapajós; 4) Há uma entrada significativa de macronutrientes, $\mathrm{Cl}$ e $\mathrm{Na}$ da agricultura de grãos intensivo nas proximidades; 5) Deposição seca é o processo mais importante para o enriquecimento de água que atinge o chão da floresta; 6) A análise de componentes principais facilita a interpretação e caracterização de águas pluviais e, neste estudo, mostra a influência de fontes antropogênicas como a agricultura, queima de biomassa, e poeira.

Palavras-chave: ciclagem de nutrientes, floresta tropical, região amazônica. 


\section{INTRODUCTION}

The Tapajós National Forest (FLONA Tapajós) has 600,000 ha of protected forest, and is situated $50 \mathrm{~km}$ to the south of the city of Santarém, Pará, Brazil, a port city of 250,000 habitants situated at the confluence of the Tapajós and Amazon Rivers.

The Santarém-Belterra Plateau, an area of 400,000 hectares (Oliveira Junior and Correa, 2001), has experienced land use change for the last 15 years due to the conversion of forest to grassland or forest to grain agriculture, and most commonly, of pasture to grain agriculture (Cohenca, 2005; Gardner et al., 2013). Today the region has about 47,000 ha with mechanized agriculture of rice, soy and corn (Pará, 2011). According to Venturieri et al. (2007), from the late 90s and early 2000s, the region of the Lower Amazon, specifically the municipalities of Santarém and Belterra, began to experience a new occupational process based on the use of mechanized agriculture.

Tropical rainforests represent a type of ecosystem that has a large influence on hydrologic processes (Jeten, 1996). The trees intercept a large part of the rainfall on the forest, a portion of which evaporates, and the portion that reaches the forest floor is determined by the intensity of the canopy and by its drainage characteristics (Jeten, 1996).

This internal circulation involves the transfer of nutrients from the vegetation to the soil through the process of canopy leaching, defined as rainfall on the canopy that passes through it and reaches the soil surface by directly falling or through stem flow (Parker, 1983). In these steps of internal circulation there is little if any intervention of decomposing microorganisms, but upon reaching the litter layer microorganisms play an important role in internal nutrient circulation (Manokaran, 1980). This process is continuous and most likely involves the recycling of nutrients over many years.

Although much research has been conducted on rainfall chemistry in temperate ecosystems, in these regions the studied forests are often monoculture plantations or forests of low species diversity, making extrapolation to highly species diverse forests difficult (Whitmore, 1975; Lloyd and Marques, 1988). In Brazil, we have some known studies about this issue in Rondonia (Germer et al., 2012) and Amazonas State (Cornu et al., 1998; Schroth et al., 2001; Honório et al., 2010).

As described by Casartelli et al. (2008), the chemistry of precipitation is a concern in developing countries because it is an efficient mechanism of removing pollutants from the air. The majority of studies published in Brazil about the chemistry of precipitation have been conducted in the south and the southeast, and in areas with a high emission from industrial and urban activities (Gonçalves et al., 2000; De Mello, 2001; Lara et al., 2001; Rocha et al., 2003; Tresmondi et al., 2003; Migliavacca et al., 2004, Souza et al., 2007). Stallard and Edmond (1981), Lesack and Melack (1991) e Honório (2010) studied rainstorms in the Amazon region looking at solute contribution to the biogeochemistry cycle in order to explain nutrient input to the ecosystem.

Dry and wet deposition can be an important nutrient source for plants, and this is especially true when soils are poor in nutrients, which is the case in the region of the Santarém-Belterra Plateau, the study area of this research. In this region, natural atmospheric nutrient deposition is enhanced by frequent biomass burning, which releases a large part of the nutrients in the above-ground biomass to the atmosphere (Kauffman et al., 1994).

The objectives of this study were: 1- to estimate total wet deposition in rainfall and throughfall, including dry deposition; 2- to verify potential nutrient sources found in the total wet deposition and dry deposition; and 3- verify possible effects of vegetative cover on nutrient content in precipitation and throughfall. 


\section{MATERIAL AND METHODS}

\subsection{Study area}

This study was conducted in the FLONA Tapajós at km 67 of the Santarém-Cuiabá Highway to the south of the city of Santarém, in the town of Belterra, western Pará State, Brazil, with geographical coordinates $02^{\circ} 54^{\prime} 23^{\prime \prime}$ south and $54^{\circ} 57^{\prime} 31^{\prime \prime}$ west (Figure 1).

Geologically, the Belterra Region is situated in the central portion of the Amazonian sedimentary basin, with the majority of its territory in the superior section of the Alter-do Chão Formation (Brasil, 1976; Embrapa, 1983; Oliveira Junior and Correa, 2001). Soils are highly weathered, deep, well-drained, kaolinitic, and classified by Oliveira Junior and Correa (2001) as Dystrofic Yellow Latosols e Dystrofic Yellow Argisols in the Brazilian Taxonomy, and in the American taxonomy as Oxisol (Haplustox) and Ultisol. The depth of the water table is approximately $120 \mathrm{~m}$.
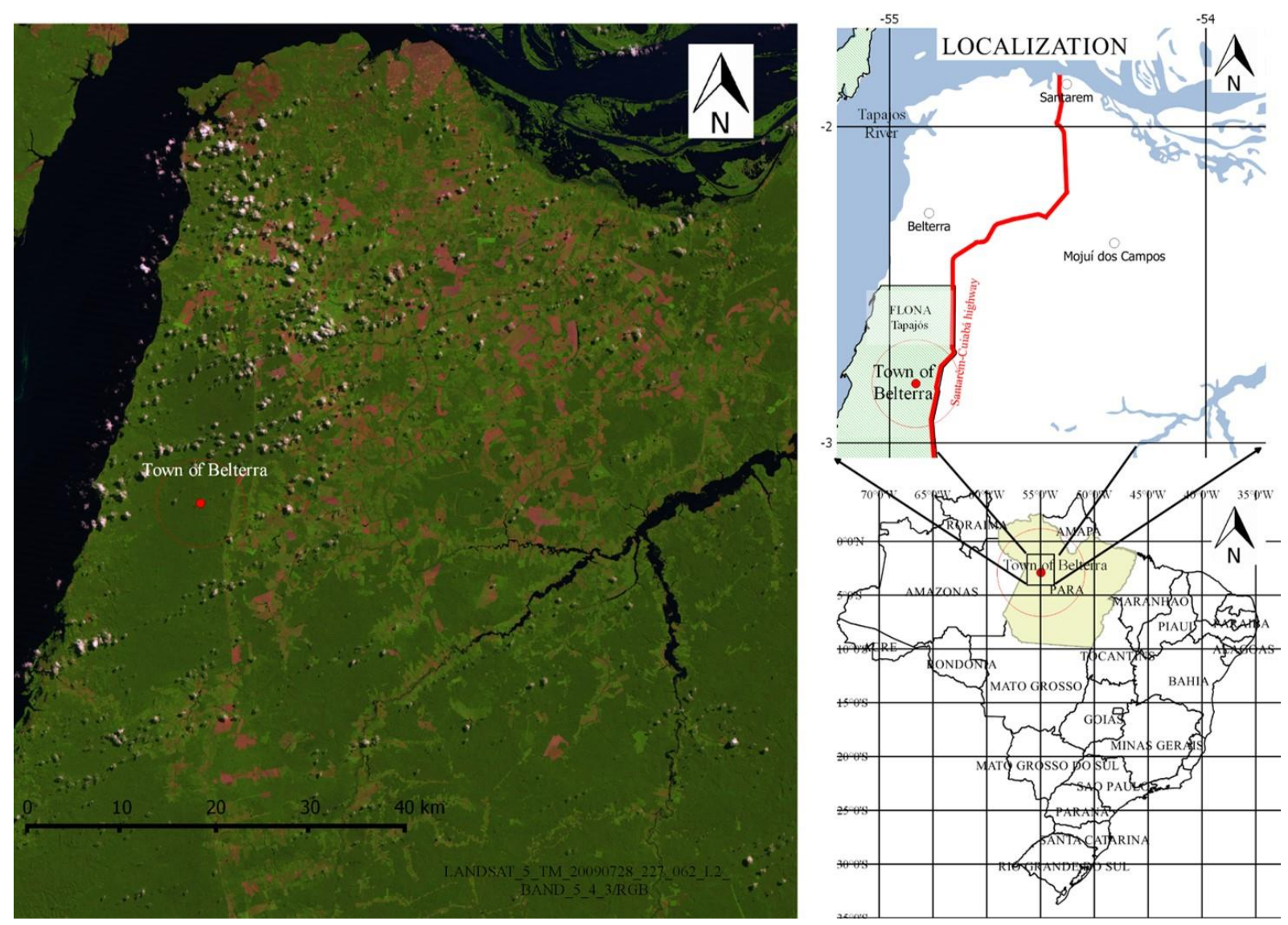

Figure 1. Soybean and rice croplands lie to the east of the site location. Image from Landsat 5, day 28/07/2009, using false color of 5, 4, and 3 bands (RGB). The color pink represents pasture and cropland.

The climate of the region is hot and humid year-round, and is classified as type Am in the Köppen classification system. Average, maximum, and minimum annual temperatures oscillate between $25-26,30-31$, and $21-23{ }^{\circ} \mathrm{C}$, respectively, while annual precipitation is around $2,000 \mathrm{~mm}$, with an irregular distribution during two seasons, with the rainy season occurring between December and June wherein $70 \%$ of annual precipitation is concentrated (Bastos, 1972; Embrapa, 1983; Parrota et al., 1995).

Figure 2 demonstrates clear pattern of a well-defined dry season starting at the end of June and ending in the month of December, a pattern that accompanies the normal climatic tendency of the last 30 years in Belterra (INMET, 1984). 
Several distinct moist and wet forest types are found within the boundaries of the FLONA Tapajós, with terra firme forest constituting approximately $33 \%$ of the forest area (Henriques et al., 2003). The equatorial evergreen seasonal forest is dominated by floristic species that are evergreen but with leaves that are slightly smaller than most evergreen species due to leaf abscission during the dry season (Parrota et al., 1995). In this forest, canopy heights range from approximately 30 to $40 \mathrm{~m}$, and there are trees that reach $50 \mathrm{~m}$ or more in height (Lefsky et al., 2005), with an understory rich in palms. Our study was conducted in terra firme forest on gently undulating upland terrain characterized by emergent species such as Bertholletia excelsa, Couratari spp., Dinizia excelsa, Hymenaea coubaril, Manilkara huberi, Parkia spp., Pithecellobium spp. and Tabebuia serratiolia.

\subsection{Sampling}

The study area consisted of a $100 \times 100 \mathrm{~m}$ plot divided into transects of $10 \times 10 \mathrm{~m}$ that were placed within a $100 \mathrm{~m}$ radius of a $65 \mathrm{~m}$ meteorological tower which collects meteorological variables such as precipitation, wind velocity and direction, incident solar radiation, and air temperature and humidity, among others.

Two L polyethylene bottles with a funnel of $115 \mathrm{~mm}$ diameter were used to collect direct precipitation (PD) on the canopy and throughfall (PI). The opening of the funnel was $1 \mathrm{~m}$ above the soil surface for PI while it was $46 \mathrm{~m}$ above for PD. Each sampling bottle was protected with aluminum foil to prevent the penetration of light and the growth of microorganisms, and nylon screen $(0.5 \mathrm{~mm}$ mesh $)$ was placed in the funnel hole to prevent the entry of insects and litterfall; weekly washing with distilled and de-ionized water was done for all bottles and funnels. Due to great variability in throughfall (Lloyd and Marques, 1988; Tobón Marin et al., 2000), and due to the structure of the tree canopy, multiple data collections are necessary when studying forest canopy rainfall interception. In order to minimize this effect, collectors were randomly dispersed in the study area each week (using EXCEL function RANDOM), with the desired effect of reducing the standard deviation of samples (Lloyd and Marques, 1988; Jetten, 1996; Tobón Marin et al., 2000).

Samples were collected weekly from April 2003 to March 2006, totaling 156 samples. Sample volume was recorded individually for each collector ( 25 collectors for throughfall and 4 for rainfall).

\subsection{Analytic procedures}

After collection, the samples were transported to the laboratory located $70 \mathrm{~km}$ from the study site in Santarém, where, on the same day, $\mathrm{pH}$ and conductivity were measured, and then the samples were filtered using cellulose acetate membranes (Millipore Corporation, Bedford, MA), with $0.22 \mu \mathrm{m}$ pore diameter.

The 25 weekly throughfall samples were bulked to form two composite samples, and five aliquots were taken from each of these composite samples and placed in $100 \mathrm{~mL}$ Nalgene flasks and stored in a freezer for posterior chemical analysis that was done on a monthly basis.

pH was measured in unfiltered samples using a pH-Tester 3 Cole-Parmer 59000-30 (Cole-Parmer Instrument Company) with a glass electrode which was calibrated weekly using standard solutions of $\mathrm{pH} 4.0,7.0$, and 10.0. Electrical conductivity was also measured in unfiltered samples using a conductivity meter (Cole-Parmer Instrument Company) calibrated using known solution concentrations (Oakton Inc., USA) following the same procedure used for the $\mathrm{pH}$ readings.

Dissolved ions $\left(\mathrm{Ca}^{+2}, \mathrm{Mg}^{+2}, \mathrm{~K}^{+}, \mathrm{Na}^{+}, \mathrm{Cl}^{-}, \mathrm{PO}_{4}^{-3}\right.$ and $\left.\mathrm{SO}_{4}{ }^{-2}\right)$ were analyzed using liquid ion chromatography Dionex DX-120 (Dionex Inc., USA). Cations were measured with a Dionex column CS12 with methanosulfuric acid as an eluente, while anions were measured using a Dionex column AS14 with carbonate and bicarbonate as an eluente. The precision of these 
analyses, here defined as values $\geq 10^{-4} \mathrm{mg} \mathrm{L}$, was less than $10 \%$, and accuracy was tested comparing standards of Dionex, Inc.

All samples for which the volume of precipitation was less than $1 \mathrm{~mm}$ each week (this represents about $16 \mathrm{~mm}$ of a total of $2000 \mathrm{~mm}$ annual volume, and is an insignificant value in this study) were discarded (no chemical analyses were conducted); but these volumes nevertheless were included in the total volume of precipitation. This was done because the capacity for saturation of forest vegetation is estimated at 0.8-1.2 mm (Jeten, 1996; Lloyd and Marques, 1998), and 16\% of the collected samples were discarded for this reason.

Interceptation (I) was calculated according to Equation 1:

$$
\mathrm{I}=((\mathrm{PD}-\mathrm{PI}) / \mathrm{PD}) * 100
$$

The fluxes F (Fpi or Fpd) were calculated, in $\mathrm{kg} \mathrm{ha}^{-1} \mathrm{year}^{-1}$, according to Equation 2, by multiplying the average monthly concentration by precipitation volume (direct and throughfall) and dividing by 100 :

$$
\mathrm{F}(\text { Fpi or Fpd })=[\mathrm{X}] * \mathrm{P}(\mathrm{PI} \text { or } \mathrm{PD}) / 100
$$

where :

$\mathrm{X}$ is a concentration of nutrient.

The calculation for net total flux (FL) was made using the Equation 3.

$\mathrm{FL}=$ throughfall flux - rainfall flux

The enrichment factor (FE) was calculated using the Equation 4 (bellow) proposed by Gordon et al. (2000). where:

$$
\mathrm{FE}=\mathrm{Cpi} / \mathrm{Cpd}
$$

Cpi is the throughfall nutrient concentration and

Cpd is the rainfall nutrient concentration. (2005).

Dry deposition (DS) was determined using the Equation 5 proposed by Zeng et al.

$$
\mathrm{DS}=\mathrm{DDF} * \text { rainfall nutrient concentration }
$$

where:

DDF is the dry deposition factor using sodium as a tracer.

DDF is calculated using Equation 6.

$\mathrm{DDF}=\left(\mathrm{PI}_{1} / \mathrm{DU}\right)_{\mathrm{Na}}$

where:

PI is net throughfall and DU is wet deposition of the sodium ion.

To predict the contribution of dry deposition of basic cations to the forest the equation of Sverdrup et al. (1990) was used (Equation 7):

$$
\mathrm{CBT}=\mathrm{DDS}_{\mathrm{Na}}\left(\mathrm{DU}_{\mathrm{Ca}}+\mathrm{DU}_{\mathrm{Mg}}+\mathrm{DU}_{\mathrm{K}}\right)
$$

where:

$\mathrm{DU}_{\mathrm{Ca}}, \mathrm{DU}_{\mathrm{Mg}}$ and $\mathrm{DU}_{\mathrm{K}}$ are wet deposition for $\mathrm{Ca}^{+2}, \mathrm{Mg}^{+2} \mathrm{e} \mathrm{K}^{+}$, respectively.

Statistical analyses were done using the software Statistica (STATSOFT, INC.). Average elemental concentrations were compared using T-tests, and principal components analysis 
(PCA) were used to compare relationships between different ions and also data variability (Hopke, 1985). This process is a simplified representation of the data that identifies relationships between the variables and suggests possible sources of these elements (Seto et al., 2000; Topcu et al., 2002; Astel et al., 2004). PCA produces a linear combination of the variables which explains a large part of the variance in the data. This combination represents the factors that are obtained when a matrix is computed between the variables. The normalized varimax rotation mode was used in this study.

\section{RESULTS}

\subsection{Rainfall and throughfall}

During the wet season, here defined as consecutive months with a volume $\geq 100 \mathrm{~mm}$, the quantity of rainfall was $1977.5 \pm 128.0 \mathrm{~mm}$ (minimum $=88 \mathrm{~mm}$ (June) and maximum $=687 \mathrm{~mm}$ (May)), while in the dry season the volume was $634.5 \pm 73.0 \mathrm{~mm}$ (minimum=28 $\mathrm{mm}$ (Sep.) and maximum $=189 \mathrm{~mm}$ (Nov.)) (Figure 2). For throughfall the volumes were 1524.6 \pm 87.2 $\mathrm{mm}$ for the wet season and $480.5 \pm 50.7 \mathrm{~mm}$ for the dry season. Monthly averages for rainfall and throughfall presented significant differences between wet and dry seasons $(\mathrm{p}<0.001)$. Average interception during the study was $19 \%$ in the wet season (minimum $=5 \%$ (May) and maximum $=40 \%$ (June)) and dry season (minimum $=2 \%$ (Sep.) and maximum $=48 \%$ (Aug.)).

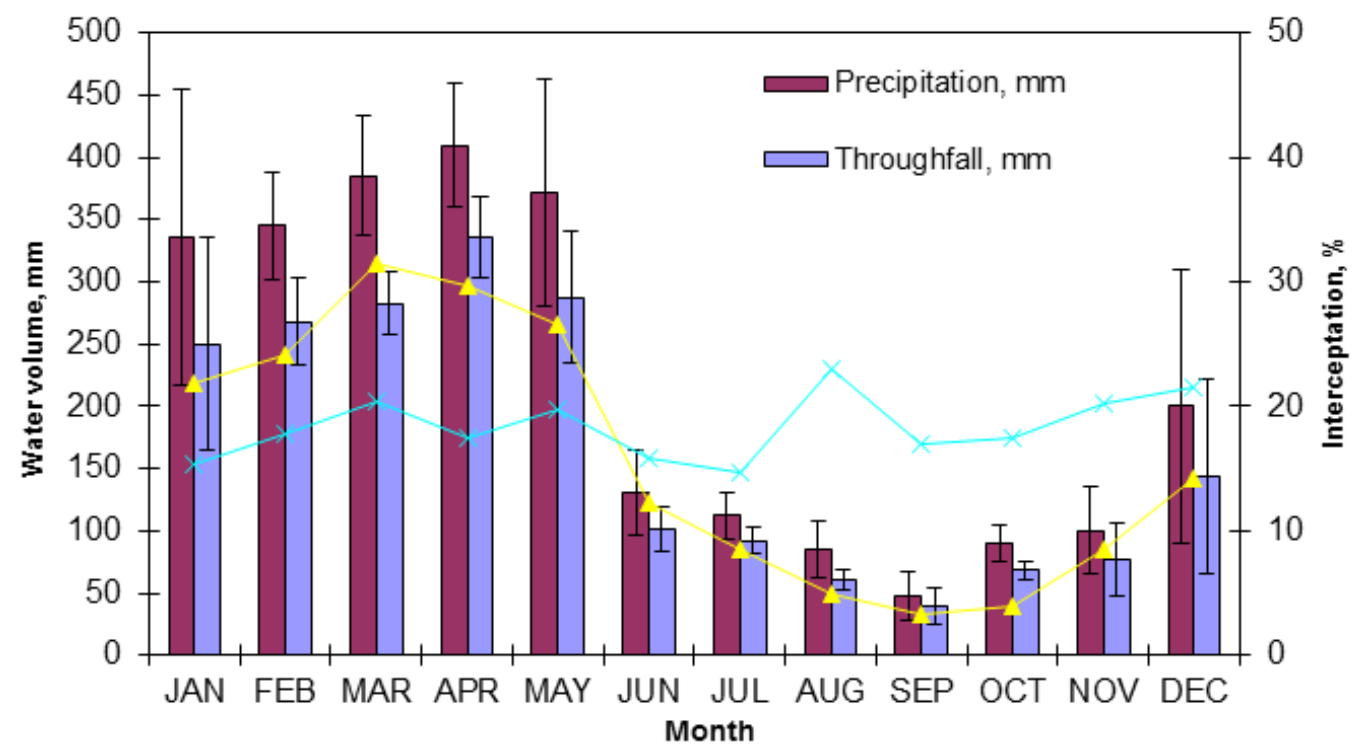

Figure 2. Rainfall and throughfall, average for three years, FLONA Tapajós. Precipitation average over 18 years in Belterra. Interception average over 3 years. Bars are standard error of the mean during study years.

\section{2. $\mathrm{pH}$ and electrical conductivity}

The results show that the $\mathrm{pH}$ of rainfall and throughfall slightly decreases at the beginning of the dry season and then increases during the wet season (Table 1). The $\mathrm{pH}$ values in direct precipitation were statistically different than those for throughfall $(\mathrm{p}<0.01)$. The $\mathrm{pH}$ values in throughfall were slightly more alkaline than this from direct precipitation (Table 1). During the rainy season and soon after it ends, there is a slight acidification in rainwater, a process that is absent for all the dry season samples.

The values for electrical conductivity (EC) presented large variation during the study period (Table 1). The largest values always occurred in the weeks with less precipitation, and there was an increase in total ion concentration in throughfall. During the wet season the largest values occurred in weeks with more precipitation, with a corresponding decrease in total ion concentration in throughfall. 
Values of $\mathrm{pH}$ in throughfall were slightly more alkaline in the direct precipitation (Table 1), with values in PD varying from 5.0 to 6.4 (Oct.) and in PI from 5.0 to 6.9 (July).

\subsection{Nutrient flux}

The flux of phosphate in direct precipitation was higher from December to May, strongly decreasing during June to November, which, in the study region, corresponds to the wet and dry seasons, respectively (Table 1). The total annual flux was $5.44 \pm 3.60 \mathrm{~kg} \mathrm{ha}^{-1}$ year. The flux of this ion in throughfall showed the same seasonal pattern as in direct precipitation, with an annual flux of $10.40 \pm 5.32 \mathrm{~kg} \mathrm{ha}^{-1}$ year (Table 1).

In direct precipitation, chloride and sulfate had annual average flux of $3.33 \pm 1.30 \mathrm{~kg} \mathrm{ha}^{-1}$ per year and $7.07 \pm 4.81 \mathrm{~kg} \mathrm{ha}^{-1}$ per year, respectively, with monthly values varying from 0.001 to $0.61 \mathrm{~kg} \mathrm{ha}^{-1}$ for chloride, and 0.001 to $1.50 \mathrm{~kg} \mathrm{ha}^{-1}$ for sulfate (Table 1). In throughfall, these fluxes varied monthly for chloride ( 0.001 to $2.04 \mathrm{~kg} \mathrm{ha}^{-1}$ ) and 0.79 a $3.14 \mathrm{~kg} \mathrm{ha}^{-1}$ for sulfate, respectively, with annual values of $11.52 \pm 6.73 \mathrm{~kg} \mathrm{ha}^{-1}$ per year for chloride and $19.51 \pm 9.861 \mathrm{~kg} \mathrm{ha}^{-1}$ per year for sulfate.

With respect to cations in direct precipitation, potassium varied monthly from 0.08 to $8.44 \mathrm{~kg} \mathrm{ha}^{-1}$; magnesium from 0.04 to $1.66 \mathrm{~kg} \mathrm{ha}^{-1}$; and calcium from 0.34 to $2.05 \mathrm{~kg} \mathrm{ha}^{-1}$, while sodium presented variation from 0.25 to $1.36 \mathrm{~kg} \mathrm{ha}^{-1}$. In throughfall, monthly flux was 2.09 to $5.05 \mathrm{~kg} \mathrm{ha}^{-1}$ for potassium, 0.73 to $2.74 \mathrm{~kg} \mathrm{ha}^{-1}$ for magnesium, 1.08 to $4.19 \mathrm{~kg} \mathrm{ha}^{-1}$ for calcium, and for sodium 0.82 to $2.54 \mathrm{~kg} \mathrm{ha}^{-1}$.

Net nutrient flux in the FLONA Tapajós (Table 1) shows that during the wet season the ions sulfate, sodium, magnesium and calcium presented high values, indicating the effect of the quantity of precipitation in the cycling of these elements in the study area.

Table 1 shows that during the rainy season there was no absorption of ions by the vegetation, except for $\mathrm{K}^{+}$.

During the dry season, ionic inputs followed the following sequence: $\mathrm{K}^{+}>\mathrm{PO}_{4}^{-3}>\mathrm{Cl}^{-}>$ $\mathrm{Na}^{+}>\mathrm{SO}_{4}^{-2}>\mathrm{Mg}^{+2}>\mathrm{Ca}^{+2}$, with values between $14.31 \mathrm{~kg} \mathrm{ha}^{-1}$ and $3.22 \mathrm{~kg} \mathrm{ha}^{-1}$ for potassium and calcium, respectively (Table 1). Ion concentration in throughfall during the wet season followed the sequence $\mathrm{Mg}^{+2}>\mathrm{K}^{+}>>\mathrm{PO}_{4}{ }^{-3}>\mathrm{Cl}^{-}>\mathrm{Ca}^{+2}>\mathrm{SO}_{4}{ }^{-2}>\mathrm{Na}^{+}$, and during the dry season it was $\mathrm{SO}_{4}^{-2}>\mathrm{Cl}^{-}>>\mathrm{K}^{+}>\mathrm{Mg}^{+2}>\mathrm{PO}_{4}^{-3}>>\mathrm{Na}^{+}>\mathrm{Ca}^{+2}$.

The sulfate ion presents a rate of internal cycling on the order of $13 \mathrm{~kg} \mathrm{ha}^{-1}$ year ${ }^{-1}$ (Table 2), a value that is eight times higher than the average reported for several polluted regions of Europe $\left(2.2 \mathrm{~kg} \mathrm{ha}^{-1} \mathrm{year}^{-1}\right)$, and for less-polluted regions in the USA in hardwood forests.

Also in Table 2, the importance of dry deposition is demonstrated through the contribution of leaching of the forest vegetation, and these data also support the hypothesis of excess application of fertilizers in nearby grain agriculture.

T-tests for element concentration in throughfall were not significant between the wet and dry seasons for phosphate, and with the exception of sulfate, all other ions showed significant differences $(\mathrm{p}<0.01)$. For direct precipitation, only chloride, sodium, and calcium ions showed significant differences $(\mathrm{p}<0.01)$. Elemental flux of $\mathrm{Cl}^{-}$was significant for throughfall $(\mathrm{p}<0.05)$, and for direct precipitation $(\mathrm{p}<0.01)$ between seasons.

The coefficient of variation for both seasons and for the entire study period, in general, shows that during the dry season there is a lower variation in elemental flux, indicating that precipitation is a decisive factor in the variation of these elements. There was also a lower elemental flux in throughfall with the exception of the chloride, sodium, and calcium ions.

When seasons are compared, the ions chloride and sodium present larger values in throughfall during the dry season, while chloride and calcium present larger flux in direct precipitation during this season. 
Table 1. Nutrients fluxes, $\mathrm{pH}$ and electrical conductivity (plus/minus mean standard error) in FLONA Tapajós, in precipitation and throughfall, during the study period (3 years). ND = Not Detected.

\begin{tabular}{|c|c|c|c|c|c|c|c|c|c|}
\hline \multicolumn{10}{|c|}{ Precipitation } \\
\hline Month & $\mathrm{PO}_{4}^{-3}$ & $\mathrm{~K}^{+}$ & $\mathrm{Mg}^{+2}$ & $\mathrm{Ca}^{+2}$ & $\mathrm{Na}^{+}$ & $\mathrm{Cl}^{-}$ & $\mathrm{SO}_{4}^{-2}$ & $\mathrm{pH}$ & $\begin{array}{c}\mathrm{CE} \mu \mathrm{S} \mathrm{cm}^{-1} \\
\mu \mathrm{S} \mathrm{cm}^{-1}\end{array}$ \\
\hline \multicolumn{10}{|c|}{$\mathrm{kg} \mathrm{ha}^{-1}$} \\
\hline Jan & $0.40 \pm 0.33$ & $2.50 \pm 1.55$ & $1.66 \pm 1.06$ & $0.95 \pm 0.04$ & $0.67 \pm 0.30$ & $0.61 \pm 0.50$ & $1.03 \pm 0.84$ & $5.7 \pm 0.45$ & $44.6 \pm 27.60$ \\
\hline $\mathrm{Feb}$ & $0.82 \pm 0.67$ & $2.28 \pm 1.83$ & $0.43 \pm 0.23$ & $0.34 \pm 0.22$ & $1.36 \pm 0.32$ & $0.004 \pm 0.003$ & $0.69 \pm 0.50$ & $6.1 \pm 0.33$ & $8.1 \pm 0.84$ \\
\hline Mar & $0.52 \pm 0.37$ & $2.01 \pm 1.25$ & $0.39 \pm 0.11$ & $0.83 \pm 0.54$ & $0.33 \pm 0.27$ & $0.01 \pm 0.01$ & $0.57 \pm 0.23$ & $6.3 \pm 0.37$ & $11.9 \pm 4.09$ \\
\hline Apr & $2.56 \pm 1.89$ & $8.44 \pm 6.62$ & $1.30 \pm 0.97$ & $0.64 \pm 0.07$ & $0.99 \pm 0.81$ & $0.22 \pm 0.17$ & $1.70 \pm 1.15$ & $6.2 \pm 0.28$ & $7.7 \pm 1.50$ \\
\hline May & $0.39 \pm 0.06$ & $0.57 \pm 0.05$ & $0.09 \pm 0.01$ & $0.25 \pm 0.08$ & $0.66 \pm 0.54$ & $0.23 \pm 0.19$ & $0.47 \pm 0.38$ & $6.2 \pm 0.11$ & $8.8 \pm 3.74$ \\
\hline Jun & $0.04 \pm 0.002$ & $0.08 \pm 0.002$ & $0.04 \pm 0.01$ & $1.05 \pm 0.33$ & $0.30 \pm 0.06$ & $0.23 \pm 0.01$ & $0.52 \pm 0.37$ & $6.2 \pm 0.46$ & $4.5 \pm 1.00$ \\
\hline Jul & $0.02 \pm 0.01$ & $0.09 \pm 0.05$ & $0.06 \pm 0.01$ & $1.56 \pm 0.34$ & $0.25 \pm 0.01$ & $0.25 \pm 0.08$ & $0.04 \pm 0.02$ & $6.3 \pm 0.59$ & $10.8 \pm 0.97$ \\
\hline Aug & $0.02 \pm 0.002$ & $0.13 \pm 0.01$ & $0.08 \pm 0.01$ & $2.05 \pm 0.66$ & $0.48 \pm 0.08$ & $0.52 \pm 0.002$ & $0.13 \pm 0.08$ & $5.7 \pm 0.73$ & $9.8 \pm 1.01$ \\
\hline Sep & $0.03 \pm 0.02$ & $0.20 \pm 0.05$ & $0.08 \pm 0.01$ & $1.56 \pm 0.10$ & $0.50 \pm 0.06$ & $0.30 \pm 0.002$ & $0.16 \pm 0.11$ & $6.1 \pm 0.36$ & $15.0 \pm 5.15$ \\
\hline Oct & $0.001 \pm 0.0005$ & $0.63 \pm 0.14$ & $0.16 \pm 0.01$ & $0.79 \pm 0.25$ & $0.36 \pm 0.08$ & $0.18 \pm 0.10$ & $0.001 \pm 0.0008$ & $6.4 \pm 0.24$ & $47.3 \pm 28.34$ \\
\hline Nov & $0.09 \pm 0.01$ & $1.47 \pm 0.32$ & $0.24 \pm 0.05$ & $0.34 \pm 0.07$ & $0.46 \pm 0.09$ & $0.44 \pm 0.06$ & $0.27 \pm 0.15$ & $6.1 \pm 0.66$ & $31.0 \pm 15.08$ \\
\hline Dec & $0.54 \pm 0.24$ & $1.72 \pm 0.91$ & $0.22 \pm 0.07$ & $0.61 \pm 0.14$ & $1.08 \pm 0.13$ & $0.31 \pm 0.18$ & $1.50 \pm 0.97$ & $5.0 \pm 0.56$ & $9.0 \pm 3.69$ \\
\hline \multicolumn{10}{|c|}{ Throughfall } \\
\hline Month & $\mathrm{PO}_{4}^{-3}$ & $\mathrm{~K}^{+}$ & $\mathrm{Mg}^{+2}$ & $\mathrm{Ca}^{+2}$ & $\mathrm{Na}^{+}$ & $\mathrm{Cl}^{-}$ & $\mathrm{SO}_{4}^{-2}$ & $\mathrm{pH}$ & $\begin{array}{c}\mathrm{CE} \mu \mathrm{S} \mathrm{cm}^{-1} \\
\mu \mathrm{S} \mathrm{cm}^{-1}\end{array}$ \\
\hline \multicolumn{10}{|c|}{$\mathrm{kg} \mathrm{ha}^{-1}$} \\
\hline Jan & $0.31 \pm 0.24$ & $2.32 \pm 1.03$ & $0.73 \pm 0.32$ & $1.32 \pm 0.53$ & $0.96 \pm 0.39$ & $1.00 \pm 0.81$ & $2.90 \pm 1.87$ & $5.0 \pm 0.65$ & $65.6 \pm 37.81$ \\
\hline $\mathrm{Feb}$ & $1.30 \pm 0.28$ & $2.76 \pm 0.22$ & $0.81 \pm 0.32$ & $1.39 \pm 0.61$ & $0.82 \pm 0.67$ & $0.07 \pm 0.06$ & $3.14 \pm 2.07$ & $6.5 \pm 0.19$ & $17.3 \pm 2.25$ \\
\hline Mar & $0.28 \pm 0.22$ & $2.98 \pm 0.15$ & $1.61 \pm 0.22$ & $2.72 \pm 0.26$ & $0.85 \pm 0.70$ & ND & $1.64 \pm 1.34$ & $6.3 \pm 0.16$ & $23.6 \pm 4.57$ \\
\hline Apr & $1.30 \pm 0.55$ & $2.58 \pm 0.72$ & $1.35 \pm 0.01$ & $2.25 \pm 0.08$ & $2.54 \pm 2.08$ & $1.73 \pm 1.41$ & $1.93 \pm 0.74$ & $6.3 \pm 0.17$ & $21.3 \pm 2.78$ \\
\hline May & $3.05 \pm 1.51$ & $2.35 \pm 0.52$ & $1.63 \pm 0.20$ & $2.80 \pm 0.24$ & $1.21 \pm 0.99$ & $0.62 \pm 0.50$ & $1.01 \pm 0.78$ & $6.4 \pm 0.23$ & $21.2 \pm 2.31$ \\
\hline Jun & $0.17 \pm 0.03$ & $2.09 \pm 0.04$ & $0.80 \pm 0.04$ & $1.08 \pm 0.10$ & $1.03 \pm 0.22$ & $0.33 \pm 0.22$ & $1.12 \pm 0.78$ & $6.6 \pm 0.21$ & $24.2 \pm 3.30$ \\
\hline Jul & $0.15 \pm 0.11$ & $2.34 \pm 0.26$ & $0.85 \pm 0.02$ & $1.17 \pm 0.11$ & $1.09 \pm 0.01$ & $0.78 \pm 0.55$ & $0.79 \pm 0.43$ & $6.9 \pm 0.21$ & $50.2 \pm 17.09$ \\
\hline Aug & $0.14 \pm 0.05$ & $2.73 \pm 0.11$ & $0.96 \pm 0.04$ & $1.19 \pm 0.21$ & $1.17 \pm 0.02$ & $2.04 \pm 0.12$ & $1.94 \pm 0.14$ & $6.1 \pm 0.35$ & $60.5 \pm 14.00$ \\
\hline Sep & $0.23 \pm 0.17$ & $2.47 \pm 0.37$ & $0.75 \pm 0.11$ & $1.02 \pm 0.05$ & $1.06 \pm 0.18$ & $1.31 \pm 0.49$ & $0.70 \pm 0.25$ & $6.2 \pm 0.66$ & $44.0 \pm 16.29$ \\
\hline Oct & $1.27 \pm 0.70$ & $3.12 \pm 0.65$ & $1.05 \pm 0.25$ & $1.25 \pm 0.15$ & $1.55 \pm 0.45$ & $1.66 \pm 1.17$ & $1.36 \pm 0.91$ & $6.2 \pm 0.44$ & $82.7 \pm 18.75$ \\
\hline Nov & $1.49 \pm 0.98$ & $2.83 \pm 1.02$ & $1.03 \pm 0.44$ & $1.32 \pm 0.44$ & $1.23 \pm 0.50$ & ND & $1.36 \pm 0.01$ & $6.0 \pm 0.63$ & $47.0 \pm 25.73$ \\
\hline Dec & $0.69 \pm 0.49$ & $5.05 \pm 2.20$ & $2.74 \pm 0.71$ & $4.19 \pm 2.24$ & $1.53 \pm 0.49$ & $1.99 \pm 1.40$ & $1.61 \pm 1.14$ & $5.6 \pm 0.46$ & $51.9 \pm 38.76$ \\
\hline
\end{tabular}


Table 2. Dry deposition flux, enrichment factor, and nutrients in liquid throughfall at the FLONA Tapajós site.

\begin{tabular}{|c|c|c|c|c|c|c|c|c|}
\hline \multirow{3}{*}{ Nutrients } & \multicolumn{3}{|c|}{ Dry Deposition } & \multirow{2}{*}{\multicolumn{2}{|c|}{$\begin{array}{c}\text { Enrichment } \\
\text { Factor }\end{array}$}} & \multirow{2}{*}{\multicolumn{2}{|c|}{$\begin{array}{l}\text { Mean net } \\
\text { throughfall }\end{array}$}} & \multirow{3}{*}{$\begin{array}{l}\text { Total net } \\
\text { throughfall }\end{array}$} \\
\hline & \multirow[t]{2}{*}{ Wet } & \multirow{2}{*}{$\frac{\text { Dry }}{\mathrm{kg} \mathrm{ha}^{-1}}$} & \multirow[t]{2}{*}{ Total } & & & & & \\
\hline & & & & WET & DRY & WET & DRY & \\
\hline Chloride & 1.32 & 4.02 & 5.35 & 4.25 & 3.47 & 2.42 & 5.76 & 8.18 \\
\hline Phosphate & 0.62 & 0.96 & 1.59 & 1.61 & 7.06 & 1.68 & 3.28 & 4.96 \\
\hline Sulphate & 3.00 & 2.84 & 5.84 & 1.61 & 8.01 & 6.77 & 5.67 & 12.44 \\
\hline Sodium & 3.64 & 4.50 & 8.15 & 1.07 & 1.88 & 3.10 & 4.49 & 7.59 \\
\hline Potassium & 2.13 & 9.61 & 11.74 & 4.58 & 10.72 & -0.79 & 14.31 & 13.51 \\
\hline Magnesium & 1.37 & 2.01 & 3.38 & 6.81 & 8.94 & 3.03 & 6.55 & 9.58 \\
\hline Calcium & 4.63 & 12.96 & 17.59 & 3.08 & 1.39 & 7.51 & 3.22 & 10.73 \\
\hline
\end{tabular}

Wet $=$ wet season; Dry $=$ dry season; Total Dep. $=$ total deposition $($ wet + dry $)$; total net throughfall $=$ (throughfall flux - precipitation flux $)$; enrichment factor $=($ net flux / precipitation flux $)$.

PCA with normalized varimax rotation (eigenvalue factors $>1.0$ ) identified three factors as potential sources of the measured elements in the FLONA Tapajós (Table 3), besides the Eigen values and commonality values. These three factors explain more than $75 \%$ of all the variance during the study period, with the factor fertilizers (Factor 1) being responsible for $40 \%$ of this explained variance. With respect to commonality, all factors except phosphate present significant values.

Table 3. Principal components analysis with variance and commonality values.

\begin{tabular}{lcccc}
\hline \multirow{2}{*}{ Nutrients } & Factor 1 & Factor 2 & Factor3 & \multirow{2}{*}{ Commonality } \\
\cline { 2 - 4 } & Fert./lime & Burning/Fert. & Fert. & \\
\hline Chloride & 0.89 & -0.08 & -0.14 & 0.71 \\
Nitrate & 0.10 & 0.20 & 0.77 & 0.42 \\
Phosphate & -0.04 & -0.06 & 0.76 & 0.22 \\
Sulphate & -0.02 & 0.90 & 0.24 & 0.85 \\
Sodium & 0.80 & -0.08 & -0.23 & 0.61 \\
Amonium & 0.07 & 0.93 & -0.07 & 0.82 \\
Potassium & 0.67 & 0.16 & 0.58 & 0.85 \\
Magnesium & 0.83 & 0.18 & 0.32 & 0.91 \\
Calcium & 0.85 & 0.08 & 0.35 & 0.92 \\
\hline Variance & 40.80 & 22.10 & 14.63 & \\
\hline
\end{tabular}

\section{DISCUSSION}

\subsection{Direct precipitation and throughfall}

Throughfall was found to be a linear function of volume of precipitation, and the equation derived from the data (Throughfall $=6.91+0.74 * \mathrm{PD}, \mathrm{r}^{2}=0.97$ ) can be used to determine the capacity of the canopy to retain water, a value which is exceed as soon as there is any measureable throughfall. We determined the capacity of the canopy to retain water integrating this equation for throughfall $=0$, which yielded the value of $9.3 \mathrm{~mm}$, which is the minimum value of rainfall for which collected samples were accepted for analysis (Johannes et al., 1986).

The relationship between throughfall and direct precipitation showed a significant linear correlation $\left(\mathrm{r}^{2}=0.96^{* *}\right.$ and $\mathrm{r}^{2}=0.98^{* *}, * *=$ significant $\left.1 \%\right)$, for the wet and dry seasons, 
respectively. According to Forti and Neal (1992), this means that the loss through interception is sufficiently regular that the precipitation signal can still be observed in throughfall. This result is in agreement with Holwerda et al. (2006) from montane rainforest in Puerto Rico who showed very high correlations of throughfall with larger precipitation volumes.

The estimated average value for throughfall (95\% significance level) as a percent of precipitation was $84 \pm 10 \%$ for the dry season, and $90 \pm 10 \%$ for the wet season, values that are similar to those of Lloyd and Marques (1988), Forti and Neal (1992), Dezzeo and Chacón (2006), and Vernimmen et al. (2007). Also, Asdak et al. (1998), working in a humid tropical forest in Indonesia that is similar to the FLONA Tapajós (580 stems/ha, canopy height of 48 $\mathrm{m}$, precipitation $=3.566 \mathrm{~mm}$ year, altitude $=100-300 \mathrm{~m}$ ), found average values for interception of $11.4 \%$, similar to the value calculated in this study; MacJannet et al. (2007) also found similar values in tropical Australia.

\subsection{Electrical conductivity and $\mathrm{pH}$}

According to Forti and Neal (1992), the acidity of rain water in tropical forests could be due to deposition of nitrate and sulfate from a source other than the oceans. For example, these authors cite Stallard and Edmond (1981), who state that reduced nitrogen from terrestrial sources and sulfur from terrestrial and marine sources are responsible for the elevated concentrations of nitrate and sulfate observed in deposition studies in the Amazon basin. These high concentrations are also found in the current study.

During the wet season there was a slight acidification in the direct precipitation, an effect that was not present in any of the dry season samples. A possible explanation for this could be the intense and inadequate use of fertilizers in nearby agricultural areas that release base cations to the atmosphere that are subsequently deposited in the forest.

The reference value usually used to compare acid precipitation to normal precipitation is $\mathrm{pH}$ 5.6, which is the $\mathrm{pH}$ resulting from the equilibrium between atmospheric $\mathrm{CO}_{2}$ with rain water (Lima and Barbin, 1975; Prakasa Rao et al., 1995). In this study $\mathrm{pH}$ of precipitation was between 5.0 and 6.3 with an average of 6.0 for all samples. However, by analyzing average values between seasons the average $\mathrm{pH}$ of precipitation is 5.8 and 6.6 for wet and dry seasons, respectively, demonstrating the importance of alkaline particles in the atmosphere, especially during the dry season. This is a likely effect of residual organic matter left on the soil surface after the harvest of rice and soy (Table 4). The increase of alkaline cations during the dry season is about $50 \%$ in comparison to the wet season, especially for calcium, which contributes four times more to $\mathrm{pH}$ than the other cations. This is an effect of the practice of liming the soils during this season.

Significant coefficients were found between electrical conductivity, precipitation, and throughfall, and similar results were found by Houbao et al. (1999) in tropical forest (Malaysia) in the rainy season. These significant regression coefficients demonstrate that EC is highly dependent on the ions present.

Table 4. $\mathrm{pH}$ values found in other locations and this study.

\begin{tabular}{llll}
\hline \multicolumn{1}{c}{ Locations } & $\mathrm{pH}$ & Range & \multicolumn{1}{c}{ References } \\
\hline Amazonia & 5.1 & $4.7-5.7$ & Stallard and Edmond (1981) \\
Amazonia & 4.7 & $4.0-5.3$ & Forti and Moreira-Nordemann \\
Venezuela & 4.6 & $3.8-6.2$ & Steinhardt and Fassbender \\
Venezuela & 4.8 & $4.4-5.2$ & Galloway et al. (1982) \\
Turrialba & 5.3 & $4.8-6.3$ & Hendry et al. (1984) \\
Trinidad & 5.8 & $5.3-6.4$ & McDowell (1988) \\
Australia & 4.8 & $4.2-5.4$ & Galloway et al. (1982) \\
Amazonia & 6.4 & $5.5-7.3$ & This work \\
\hline
\end{tabular}




\subsection{Net flux and enrichment factor}

The enrichment factor (FE) for the analyzed elements followed the sequence $\mathrm{Mg}^{+2}>\mathrm{K}^{+}$ $>\mathrm{Cl}^{-}>\mathrm{Ca}^{+2}>\mathrm{SO}_{4}{ }^{-2}>\mathrm{PO}_{4}^{-3}>\mathrm{Na}^{+}$, during wet season. In the dry season the sequence was $\mathrm{K}^{+}$ $>\mathrm{Mg}^{+2}>\mathrm{SO}_{4}{ }^{-2}>\mathrm{PO}_{4}^{-3}>\mathrm{Cl}^{-}>\mathrm{Na}^{+}>\mathrm{Ca}^{+2}$. This factor provides a relative measure of the quantity of the material that has been leached from the vegetation and incorporated into the rain water as it passes across the vegetation surface (Forti et al., 2000). The enrichment of potassium in throughfall indicates that the largest proportion of this element is leached from the vegetation.

Net throughfall input of $\mathrm{SO}_{4}{ }^{-2}$ results from canopy leaching, dry deposition, and stemflow, besides any other interactions with leaf surfaces. Leaf interaction can occur as inputs through leaching and runoff and as losses through leaf absorption. Under the assumption that leaf interaction is relatively insignificant, Table 2 indicates that dry deposition is the major source of sulfur in the FLONA Tapajós (Lindberg and Garten, 1988).

Table 2 shows that dry deposition is the principal process through which nutrients enter into the forest, principally calcium, sodium, chlorine and potassium. Using Equations 4 and 5, dry deposition of particulates was estimated for elements analyzed in this study (Table 2). These Equations (4 and 5) are widely used to estimate particulate dry deposition for many substances (Bredemeier, 1988; Godt and Weyer, 1989; Ivens, 1990; Zeng et al., 2005). It is important to remember that this equation assumes that there is no exchange between the vegetation and rain water percolating through the vegetation surface.

High sodium concentrations were observed (Table 2), and were higher than those generally in the Amazon region and in tropical forests (Franken et al., 1985; Forti and Neal, 1992; Cornu et al., 1998). We suggest that a large part of this sodium could be brought by easterly winds during the dry season passing over saline soils in areas to the east of our study area.

In general, $\mathrm{Ca}^{+2}, \mathrm{Mg}^{+2}$ e $\mathrm{K}^{+}$are subject to canopy leaching (Parker, 1983). This could significantly contribute to the flux of $\mathrm{Ca}^{+2}, \mathrm{Mg}^{+2}$ in throughfall, especially in areas where there is a substantial input of $\mathrm{NH}_{4}{ }^{+}$, thus causing exchange between basic cations and $\mathrm{NH}_{4}{ }^{+}$. (Roelofs et al., 1985). This situation appears to be occurring in the FLONA Tapajós.

\subsection{Nutrient fluxes}

A positive and strong correlation $(r=0.95)$ between magnesium and calcium in throughfall (Figure 3) supports the hypothesis that the flux of these elements is coming from the same source, namely fertilizer and dolomitic lime applied in nearby agricultural fields, besides the normal contribution from dry deposition which causes the accumulation of these nutrients.

It is usually assumed that the concentration of potassium in throughfall is entirely due to canopy leaching, and therefore that the contribution of dry deposition is practically zero (Parker, 1983). However, we suggest that a substantial quantity of potassium reaches the forest through dry deposition due to the excess application of potassium-based fertilizers, principally potassium chloride, in the soy and rice crops located to the northeast of the FLONA Tapajós. Positive and significant $r^{2}$ shown in this study in precipitation and throughfall permits the inference that agriculture contributed to potassium deposition in the FLONA Tapajós.

According to Kaupenjohann (1997), the annual requirement for magnesium needed by forests to produce biomass and to account for measured canopy leaching is in the range of $3-30 \mathrm{~kg} \mathrm{ha}^{-1}$ year $^{-1}$. In the current study, the flux of $\mathrm{Mg}^{+2}$ was $14 \mathrm{~kg} \mathrm{ha}^{-1}$ year ${ }^{-1}$. The stock of $\mathrm{Mg}$ in the above-ground biomass can often exceed the exchangeable pool in the soil, as in the

Rev. Ambient. Água vol. 10 n. 2 Taubaté - Apr. / Jun. 2015 
FLONA Tapajós. Given this situation, the input of $\mathrm{Mg}^{+2}$ in throughfall is of fundamental importance to the cycling of this cation in the forest ecosystem (Ambruster et al., 2002).

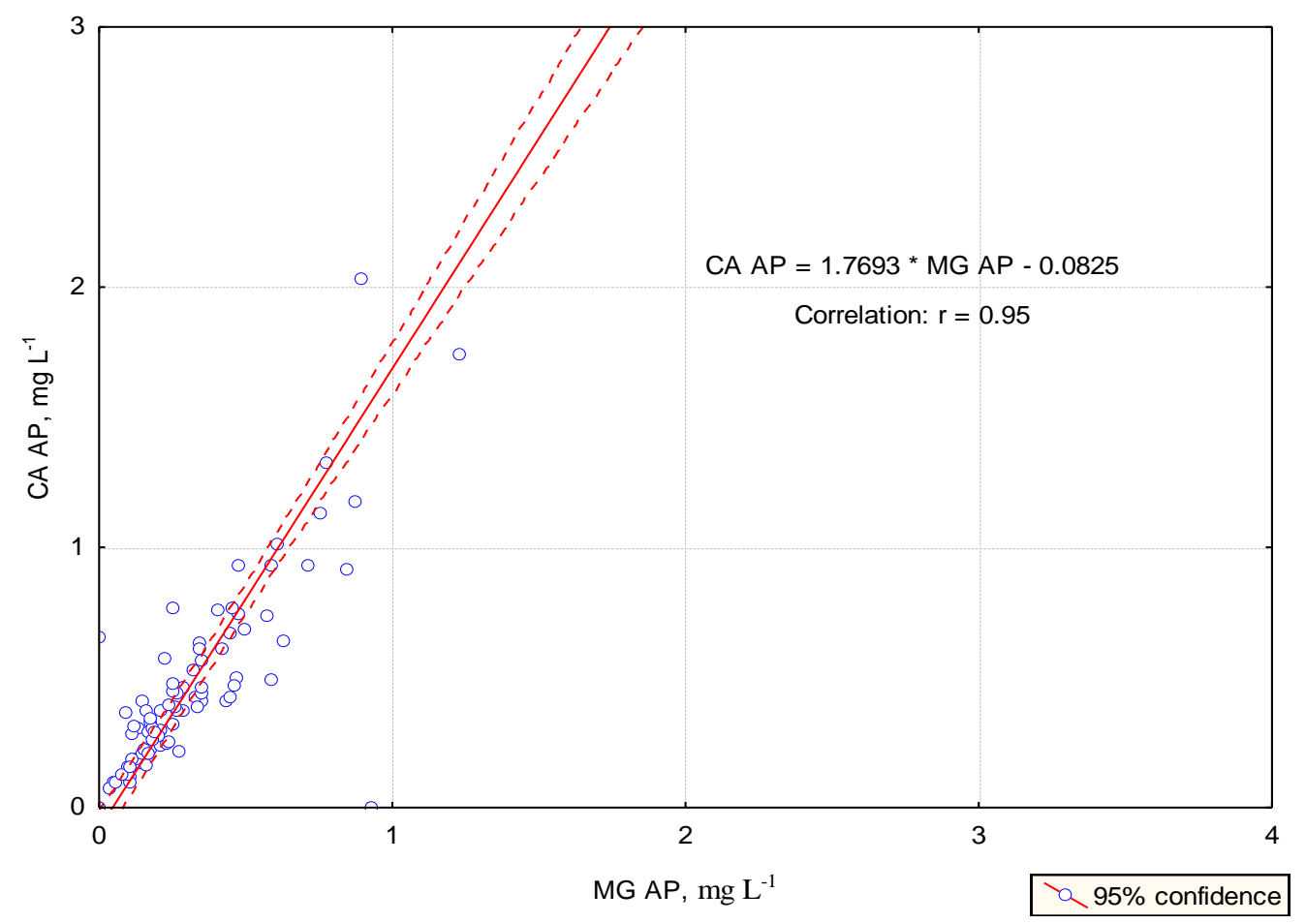

Figure 3. Positive and significant correlation of calcium $x$ magnesium in throughfall during the study period (3 years). $\mathrm{CA} A \mathrm{P}=$ Calcium in throughfall $\left(\mathrm{mg} \mathrm{L}^{-1}\right) ; \mathrm{MG}$ $\mathrm{AP}=$ Magnesium in throughfall $\left(\mathrm{mg} \mathrm{L}^{-1}\right)$.

Since the largest source of $\mathrm{Mg}^{+2}$ in unfertilized forest soils (natural or native forests) is from atmospheric deposition and the weathering of parent material (Feger, 1997) and that the parent material of the FLONA Tapajós is poor in this element (Brasil, 1976), we can conclude that atmospheric deposition is the most important source of $\mathrm{Mg}^{+2}$ in this forest. Furthermore, analysis of NPK fertilizers used in the region found $\mathrm{Mg}^{+2}$ concentrations twice as high as those measured in this study.

Assuming that the input of $\mathrm{Na}^{+}$is from marine sources, an element $\mathrm{X}$ also originating from a marine source should have the same ratio $\mathrm{X}: \mathrm{Na}$ in dry deposition; if there are other important sources then this ratio will be lower than that originating from marine sources (Beier et al., 1992). Following this reasoning, the X:Na originating from marine sources is $\mathrm{Na} / \mathrm{K}=27.02 ; \mathrm{Na} / \mathrm{Ca}=26.17 ; \mathrm{Na} / \mathrm{Mg}=8.4$, and $\mathrm{Na} / \mathrm{SO}_{4}{ }^{-2}=3.97$ (Franzen, 1990). Based on these assumptions, the input of marine-sourced elements from throughfall into the FLONA Tapajós is shown in Table 5. The data show 3.70; $11.90 ; 3.82$ and $25.19 \%$, for $\mathrm{K}^{+}, \mathrm{Mg}^{+2}, \mathrm{Ca}^{+2}$ and $\mathrm{SO}_{4}{ }^{-2}$, respectively. These results could be explained assuming a marine source, which would support the hypotheses of a large influence over the addition of these elements from the practices of fertilizer use and soil correction prevalent in intensive grain agriculture in the region. The ratios of $\mathrm{K}^{+}$and $\mathrm{Ca}^{+2}$ are 73 and 39 times higher than those of seawater, while the ratio $\mathrm{SO}_{4}{ }^{-2} / \mathrm{Na}^{+}$is four times higher. In addition, the highest values are found during the dry season, which contradicts Lesack and Melack (1991) and Stallard and Edmond (1981). In contrast to Lesack and Melack (1991), in the current study it is suggested that the emission from fertilizers excessively and incorrectly applied to nearby agricultural areas, coupled with the use of fire to clear areas, are the principal sources for the high values found in this study. 
Table 5. The $\mathrm{X} / \mathrm{Na}$ ratio showing the role of fertilizer and liming use near the forest.

\begin{tabular}{|c|c|c|c|c|c|}
\hline \multirow{2}{*}{ Molar ratio } & \multicolumn{2}{|c|}{ FLONA - km 67} & \multirow{2}{*}{ FLONA km 67} & \multirow{2}{*}{$\begin{array}{c}\text { Central } \\
\text { Amazônia }^{1}\end{array}$} & \multirow{2}{*}{ Sea water ${ }^{2}$} \\
\hline & Wet & Dry & & & \\
\hline $\mathrm{Cl}^{-} / \mathrm{Na}^{+}$ & 0.32 & 0.65 & 0.45 & 1.1 & 1.80 \\
\hline $\mathrm{SO}_{4}^{-2} / \mathrm{Na}^{+}$ & 1.22 & 0.66 & 0.95 & 0.82 & 0.25 \\
\hline $\mathrm{K}^{+} / \mathrm{Na}^{+}$ & 3.98 & 1.35 & 2.70 & 0.08 & 0.12 \\
\hline $\mathrm{Mg}^{+2} / \mathrm{Na}^{+}$ & 0.93 & 0.27 & 0.64 & 0.20 & 0.12 \\
\hline $\mathrm{Ca}^{+2} / \mathrm{Na}^{+}$ & 1.01 & 2.19 & 1.47 & 0.18 & 0.04 \\
\hline
\end{tabular}

Fonte: ${ }^{1}$ Lesack and Melack (1991); ${ }^{2}$ Schlesinger (1997). FLONA - km 67 is divided by season; FLONA km 67 represents the entire sampling period.

Atmospheric deposition has two principal sources: marine salts and mineral particles originating from dust from soil or mining operations, combustion, and other industrial processes; in this study we can also include intensive grain agriculture. Table 5 shows the small contribution from marine sources, calculated using the X:Na ratio, and since industrial processes are non-existent in the region the only other possibilities for atmospheric deposition are burning and the deposition of materials originating from grain agriculture as the principal source of $\mathrm{SO}_{4}^{-2}, \mathrm{Mg}^{+2}, \mathrm{Ca}^{+2}$ and $\mathrm{K}^{+}$in the FLONA Tapajós. Furthermore, the fact that the ratio $\mathrm{Mg} / \mathrm{Na}(0.64)$ by is three times higher than the oceans $(0.227)$, suggests that the input of $\mathrm{Mg}$ comes from the excessive use of fertilizers and correctives in grain agriculture in the region.

In this study, after the use of Equation 7, monthly values of $F_{\mathrm{Na}}$ were calculated, and CBT presented values of 51.6 and $56.1 \mathrm{~kg} \mathrm{ha}^{-1}$ year $^{-1}$, during the years of the study, with an average contribution of $21.9 \%$ for sodium, $14.6 \%$ for potassium, and $7.0 \%$ for magnesium

Using data for precipitation and throughfall as a base, several models have been developed to estimate dry deposition, such as multiple regression models (Lovett et al., 1996; Fan and Hong 2001), and the Na-ratio approach (Bredemeier 1988), and also for cation leaching from canopies (Fan and Hong 2001; Zeng et al., 2005). In this study we used the method proposed by Ulrich (1983) (Table 6), which is based on several assumptions. Dry deposition and vegetation exchange of $\mathrm{Ca}^{+2}, \mathrm{Mg}^{+2}$ and $\mathrm{K}^{+}$are calculated using $(a)$ total deposition instead of just wet deposition; $(b)$ particles containing these nutrients are deposited with the same efficiency as $\mathrm{Na}^{+}$, and (c) the ratio of dry:wet deposition of these particles (Devlaeminck et al., 2004).

Table 6. Canopy leaching values in the FLONA Tapajós during two years.

\begin{tabular}{lccc}
\hline Month & $\mathrm{K}$ & $\mathrm{Mg}$ & $\mathrm{Ca}$ \\
\hline Year 1 & 5.37 & 3.95 & -5.65 \\
Year 2 & -1.94 & 8.44 & -8.65 \\
Wet & -5.85 & 3.33 & 5.76 \\
Dry & 9.28 & 9.07 & -20.06 \\
Average & 0.14 & 0.52 & -0.60 \\
TOTAL & 3.43 & 12.40 & -14.30 \\
\hline
\end{tabular}

Rev. Ambient. Água vol. 10 n. 2 Taubaté - Apr. / Jun. 2015 
The dry deposition factor of the FLONA Tapajós ( $\mathrm{km} 67)$ was higher during the dry season (2.70). Seasonal differences in dry deposition onto forest canopies are influenced by characteristics of the vegetation that, in large part, are linked to the scale and dimensions of the vegetation (Ivens, 1990). Canopy leaching of basic cations $\left(\mathrm{K}^{+}, \mathrm{Mg}^{+2}, \mathrm{Ca}^{+2}\right)$, demonstrates the role of absorption and emission of these nutrients (Table 6). When using the equation of Ulrich (1983), during the dry season, calcium is strongly absorbed by the vegetation $\left(20 \mathrm{~kg} \mathrm{ha}^{-1}\right.$ year $\left.^{-1}\right)$, while potassium is absorbed during the wet season $\left(6 \mathrm{~kg} \mathrm{ha}^{-1}\right.$ year $\left.{ }^{-1}\right)$, and magnesium is emitted during both seasons. This is probably due to the measured high concentrations of this element, which surpass the absorption capacity of the vegetation.

Dry deposition differs among forests, depending on the characteristics of the element, and is generally higher than atmospheric inputs measured by collectors of total deposition (Lindberg et al., 1986; Hansen, 1995; Stoorvogel et al., 1997). For this reason, it is difficult to measure the proportion of canopy exchange and dry deposition in throughfall (Laclau et al., 2003). Using the qualitative method employed by Laclau et al. (2003), the change in the correlation coefficients between cations and anions as they pass through the forest canopy suggests that there is at least some ion exchange occurring with the canopy. In the FLONA Tapajós all cations were poorly correlated with $\mathrm{Cl}^{-}, \mathrm{NO}_{3}^{-}$e $\mathrm{SO}_{4}^{-2}$ in precipitation, while in throughfall there were strong and significant correlations, suggesting high levels of exchange within the canopy.

In an attempt to group the different factors influencing the chemistry of precipitation and throughfall, principal components analysis was used. The results show that the correlations are high between components of the same group, varying between 0.58 and 0.89 , and explain more than $77 \%$ of the variation (Table 3). Factor 1, encompassing chloride, sodium, potassium, and magnesium, is clearly a signal representing fertilization and soil correction activities conducted in nearby intensive mechanized agricultural areas (Shen et al., 2013) wherein potassium chloride and dolomite lime are applied in the proportion of 400 and 2,000 $\mathrm{kg}$ ha, respectively.

Results for factor 2 (Table 3), ammonium sulfate, are in line with correlations that would be expected for fires from vegetation burning (Nardoto and Bustamante, 2003), and for use of sulfate fertilizers such as triple superphosphate, and also the transformation of urea into ammonium with subsequent hydrolysis and release to the atmosphere. The fact that the soil is naturally acidic could be brought up as a counterpoint to these results; however, the urea added to the soil after correction with lime elevates its $\mathrm{pH}$ to approximately 6.5 , thus promoting the process of ammonification.

Factor 3 (Table 3), nitrate, phosphate, and potassium, exemplifies the role of particulate dry deposition from fertilizer application and subsequent emission, by the vegetation, of aerosols containing these elements, in agreement with data from Artaxo et al. (1990), Forti and Moreira-Nordeman (1991a), and Lesack and Melack (1991).

Communality values, with exception of those for phosphate, were elevated and significant. Communality expresses, for each element, the total percentage of the original variance explained by the three factors. The results show that phosphate has other sources that are not explained by the principal components analysis.

The correlation between potassium and chlorine also indicates a common origin in throughfall, and these data also support the hypothesis of excess application of fertilizers in nearby grain agriculture.

Finally, although the quantity of precipitation is an important factor in nutrient flux, especially for rainfall events of up to $10 \mathrm{~mm}$ (Tanner and Wong, 2000), it is not the variable responsible for the large variation measured in this study, demonstrating that local factors (Tanner and Fai, 2000), are anthropogenic (fires and application of fertilizers and soil 
correctives, for example), and natural (saline soils) also of great importance to the chemical composition of precipitation in the FLONA Tapajós.

\section{CONCLUSIONS}

This research has shown that there is substantial seasonal variation in ion flux in this Amazonian forest, with seasonality exerting a strong influence on the concentration of basic cations and greater variation in ion flux in the dry season. Dry deposition throughfall is one of the most important paths for input of nutrients into the FLONA Tapajos, and is the most important process for the enrichment of water that reaches the forest floor. Principal components analysis showed the influence of anthropogenic sources such as agriculture, biomass burning, and dust, and that there is a significant input of macronutrients, $\mathrm{Cl}$ and $\mathrm{Na}$ from nearby intensive grain agriculture. Furthermore, the correlation between $\mathrm{K}$ and $\mathrm{Cl}$ in throughfall supports the hypothesis of deposition of these constituents into the forest due to excess application of fertilizers in nearby grain agriculture. These results clearly demonstrate the effects that mechanized agricultural practices can have on forests in this region, and suggest the need for modification of current agricultural management practices such as tillage and fertilizer application in order to avoid changes in water chemistry in neighboring forests.

\section{ACKNOWLEDGMENT}

The authors thank the TG-07 research group of the LBAECO project for funding of this work. We would also like to thank the Ecophysiology Laboratory at Embrapa, Belém, and Candido Moura and José Augusto for use of the UFPA laboratory. Finally, we thank field assistant Cleuton Pereira for his collaboration, patience and availability every day to go to the field. Work funded by TG-07 project (LBAECO); a chapter of the doctor degree of first author.

\section{REFERENCES}

AMBRUSTER, M.; MACDONALD, J.; DISE, N. B.; MATZNER, E. Throughfall and output fluxes of $\mathrm{Mg}$ in European forest ecosystem: a regional assessment. For. Ecol. Manage, v. 164, p. 137-47, 2002. http://dx.doi.org/10.1016/S0378-1127(01)00606-5

ARTAXO, P.; MAENHAUT, W.; STORMS, H.; VAN GRIEKEN, R. Aerosol characteristics and sources for the Amazon basin during wet season. J Geophys Res, v. 95, n. D10, p. 16971-85, 1990. http://dx.doi.org/10.1029/JD095iD10p16971

ASDAK, C.; JARVIS, P. G.; GARDINGEN, P. V. Rainfall interception loss in unlogged and logged forest areas of Central Kalimantan, Indonesia. J Hydrol, v. 206, p. 237-244, 1998. http://dx.doi.org/10.1016/S0022-1694(98)00108-5

ASTEL, A.; MAZERSKI, J.; POLKOWSKA, Z.; NAMIE’SNIK, J. Application of PCA and time series analysis in studies of precipitation in Tricity (Poland). Adv Environ Res, v. 8, p. 337-349, 2004. http://dx.doi.org/10.1016/S1093-0191(02)00107-7

BASTOS, T. X. O estado atual dos conhecimentos das condições climáticas da Amazônia brasileira. In: IPEAN. Zoneamento agrícola da Amazônia. Belém, 1972. p. 68-122. (Boletim Técnico, 54). 
BEIER, C.; GUNDERSEN, P.; RASMUSSEN, L. A new method for estimation of dry deposition of particles based on throughfall measurements in forest edge. Atmos Environ, v. 26A, n. 9, p. 1553-59, 1992. http://dx.doi.org/10.1016/09601686(92)90055-P

BRASIL. Departamento Nacional da Produção Mineral. Projeto RADAMBRASIL. Folha SA - 21 - Santarém: geologia, geomorfologia, solos, vegetação uso potencial da terra. Rio de Janeiro, 1976. 522 p. (Levantamento de Recursos Naturais, 10)

BREDEMEIER, M. Forest canopy transformation of atmospheric deposition. Water Air Soil Pollut, v. 40, p. 121-38, 1988. http://dx.doi.org/10.1007/978-94-009-0923-6_8

CASARTELli, M. R.; MIRLEAN, N.; PERALBA, M. C.; BARRIONUEVO, S.; GÓMEZREY, M. X.; MADEIRA, M. An assessment of the chemical composition of precipitation and throughfall in rural-industrial gradient in wet subtropics (southern Brazil). Environ Monit Assess, v. 144, p. 105-116, 2008. http://dx.doi.org/10.1007/s10661-007-9949-y

COHENCA, D. A. Expansão da fronteira agrícola e sua relação com o desmatamento detectado em imagens Landsat TM e ETM+ na região norte da BR-163, Pará entre os anos de 1999 a 2004. 2005. 23 p. Monografia (Gestão e Manejo Ambiental em Sistemas Florestais) - Universidade Federal de Lavras, Santarém, 2005.

CORNU, S.; AMBROSE, J. P.; LUCAS, Y.; DESJARDINS, T. Origin and behavior of dissolved chlorine and sodium in Brazilian rainforest. Water Resour, v. 32, p. 1151-61, 1998. http://dx.doi.org/10.1016/S0043-1354(97)00298-4

DE MELLO, W. Z. Precipitation chemistry in the coast of the metropolitan region of Rio de Janeiro, Brazil. Environ Pollut, v. 114, p. 235-242, 2001. http://dx.doi.org/ 10.1016/S0269-7491(00)00209-8

DEVLAEMINCK, R.; SCHRIJVER, A.; HERMY, M. Variation in throughfall deposition across a deciduous beech (Fagus sylvatica) forest edge in Flanders. Sci Total Environ, v. 337, p. 241-252, 2004. http://dx.doi.org/10.1016/j.scitotenv.2004.07.005

DEZZEO, N.; CHACÓN, N. Nutrient fluxes in incident rainfall, throughfall, and stemflow in adjacent primary and secondary forests of the Gran Sabana, southern Venezuela. For Ecol Manage, v. 234, p. 218-226, 2006. http://dx.doi.org/10.1016/j.foreco.2006.07.003

EMPRESA BRASILEIRA DE PESQUISA AGROPECUÁRIA - EMBRAPA. Serviço Nacional de Levantamento e Classificação de Solos. Levantamento de reconhecimento de média intensidade dos solos e avaliação da aptidão agrícola das terras do Pólo Tapajós. Rio de Janeiro, 1983. 284 p. (Boletim de Pesquisa, 20)

FAN, H. B.; HONG, W. Estimation of dry deposition and canopy Exchange in Chinese fir plantations. For Ecol Manag, v. 130, p. 99-107, 2001. http://dx.doi.org/10.1016/S03781127(00)00469-2

FEGER, K. H. Biogeochemistry of Mg in forest ecosystems. In: HUTTL, R. F.; SCHAAF, W. (Eds.). Magnesium deficiency in forest ecosystems. Dordrecht: Kluwer Academic Publishers, 1997. p. 67-99. 
FORTI, M. C.; BOULET, R.; MELFI, A. J.; NEAL, C. Hydrogeochemistry of a small catchment in northeastern Amazonia: a comparison between natural with deforested parts of the catchment (Serra do Navio, Amapa State, Brazil). Water Air Soil Pollut, v. 118, p. 263-79, 2000. http://dx.doi.org/10.1023/A:1005155706417

FORTI, M. C.; MOREIRA-NORDEMANN, L. M. An ion budget for a "terra firme" ecosystem in Central Amazonia. In: BEAGA Jr., B. P. F.; FEMNANDEZ-.JOUREQUI, C. A. (Eds.). Water management of the Amazon basin. [S.1.]: ROSTLAC-UNESCO, 1991a. p. 13-18.

FORTI, M. C.; NEAL, C. Spatial variability of throughfall chemistry in a tropical rainforest (Central Amazonia, Brazil). Sci Total Environ, v. 120, p. 245-59, 1992. http://dx.doi.org/10.1016/0048-9697(92)90059-2

FORTI, M. C.; MOREIRA-NORDEMANN, L. M. Rainwater and throughfall chemistry in a "terra firme" rainforest-Central Amazonia. J Geophys Res, v. 96, p. 7415-21, 1991b. http://dx.doi.org/10.1029/90JD02170

FRANKEN, W.; LEOPOLDO, P. R.; BERGAMIN, H. Nutrient flow through natural waters in "terra firme" forest in Central Amazon. Turrialba, v. 35, p. 383-93, 1985.

FRANZEN, L. G. Transport, deposition and distribution of marine aerosols over southern Sweden during dry westerly stroms. Ambio, v. 19, p. 180-188, 1990. http://www.jstor.org/stable/4313690

GALlOWAY, J. N.; LIKENS, G. E.; KEENE, W. C.; MILLER, J. M. The composition of precipitation in a remote areas of the world. J Geophys Res, v. 87, p. 8771-86, 1982. http://dx.doi.org/10.1029/JC087iC11p08771

GERMER, S.; ZIMMERMANN, A.; NEILL, C.; KRUSCHE, A.V.; ELSENBEER, H. Disproportionate single-species contribution to canopy-soil nutrient flux in an Amazonian rainforest. For. Ecol Manage, v. 267, p. 40-49, 2012. http://dx.doi.org/10.1016/j.foreco.2011.11.041

GARDNER, T. A.; FERREIRA, J.; BARLOW, J.; LEES, A. C.; PARRY, L.; VIEIRA, I. C. et al. A social and ecological assessment of tropical land uses at multiple scales: the Sustainable Amazon Network. Philos. Trans R Soc Lond B: Biol Sc, v. 368, p. 20120166-20120166, 2013.

GODT, J.; WEYER, M. Input of sulphur and acidity in three spruce stands in the vicinity of a strong $\mathrm{SO}_{2}$ source. In: GEORGII, H. W. (Ed.). Mechanisms and effects of pollutanttransfer into forests. New York: Kluwer Academic Publishers, 1989.

GONÇALVES, F. L. T.; MASSAMBANI, O.; BEHENG, K. D.; VAUTZ, W.; SCHILLING, M.; SOLCI, M. C. et al. Modelling and measurements of below cloud scavenging processes in the highly industrialized region of Cubatão-Brazil. Atmos Environ, v. 34, p. 4113-4120, 2000. http://dx.doi.org/10.1016/S1352-2310(99)00503-8

GORDON, A. M.; CHOURMOUZIS, C.; GORDON, A. G. Nutrient inputs in litterfall and rainwater fluxes in 27-years old red, black and white spruce plantations in Central Ontario, Canada. For Ecol Manage, v. 138, p. 65-78, 2000. http://dx.doi.org/10.1016/S0378-1127(00)00412-6 
HENRIQUES, L. M. P.; WUNDERLE, Jr., J. M.; WILLIG, M. R. Birds of the Tapajos national forest, Brazilian Amazon: a preliminary assessment. Ornit Neotrop, v. 14, p. $1-32,2003$.

HANSEN, K. In-canopy throughfall measurements in Norway spruce: water flow and consequences for ion fluxes. Water Air Soil Pollut, v. 85, p. 2259-2264, 1995. http://dx.doi.org/10.1007/BF01186170

HENDRY, D. C.; BERISH, C. W.; EDGERTON, E. S. Precipitation chemistry at Turrialba, Costa Rica. Water Res Res, v. 20, p. 1677-84, 1984. http://dx.doi.org/10.1029/WR020i011p01677

HONÓRIO, B. A. D.; HORBE, A. M. C.; SEYLER, P. Chemical composition of rainwater in western Amazonia - Brazil. Atmos Res, v. 98, p. 416-425, 2010. http://dx.doi.org/10.1016/j.atmosres.2010.08.001

HOPKE, P. K. Receptor modeling in environmental chemistry. New York: Wiley, 1985. $454 \mathrm{p}$.

HOUBAO, F.; WEI, H.; ZHUANG, M.; KOSUKE, W. Acidity and chemistry of bulk precipitation, throughfall and stemflow in a Chinese fir plantation in Fujian, China. For Ecol Manage, v. 122, p. 243-48, 1999.

http://dx.doi.org/10.1016/S0378-1127(99)00011-0

HOLWERDA, F.; SCATENA, F. N.; BRUIJNZEEL, L. A. Throughfall in a Puerto Rican lower montane rainforest: a comparison of sampling strategies. J Hydrol, v. 327, p. 5920602, 2006. http://dx.doi.org/10.1016/j.jhydrol.2005.12.014

INSTITUTO NACIONAL DE METEOROLOGIA - INMET (Brasil). Normais climatológicas. Rio de Janeiro, 1984. 125 p.

IVENS, W. P. M. F. Atmospheric deposition onto forest: an analysis of the deposition variability by jeans of throughfall measurements. 1990. 151p. PhD Thesis - Utrecht University, Utrecht, 1990.

JETTEN, V. G. Interception of tropical rain forest performance of a canopy water balance model. Hydrol Process, v. 10, p. 671-685, 1996. http://dx.doi.org/10.1002/(SICI)10991085(199605)10:5<671::AID-HYP310\%3e3.0.CO;2-A

JOHANNES, A. H.; CHEN, Y. L.; DACKSON, K.; SULESKI, T. Modeling of throughfall chemistry and indirect measurement of dry deposition. Water Air Soil Pollut, v. 30, p. 211-216, 1986. http://dx.doi.org/10.1007/BF00305191

KAUFFMAN, J. B.; CUMMINGS, D. L.; WARD, D. E. Relationships of fire, biomass, and nutrient dynamics along a vegetation gradient in the Brazilian Cerrado. J Ecol, v. 82, p. 519-531, 1994. http://www.jstor.org/stable/2261261

KAUPENJOHANN, M. Tree nutrition. In: HUTTL, R. F.; SHAAF, W. (Eds.). Magnesium deficiency in forest ecosystem. Dordrecht: Kluwer Academic Publishers, 1997.

LACLAU, J. P.; RANGER, J.; BOUILLET, J. P.; NZILA, J. D.; DELEPORTE, P. Nutrient cycling in a clonal stand of Eucaliptus and an adjacent savanna ecosystem in Congo. I. Chemical composition of rainfall, throughfall and stemflow solutions. For Ecol Manage, v. 176, p. 105-19, 2003. http://dx.doi.org/10.1016/S0378-1127(02)00280-3 
LARA, L. B. L. S.; ARTAXO, P.; MARTINELLI, L. A.; VICTORIA, R. L.; CAMARGO, P. B.; KRUSCHE, A. et al. Chemical composition of rainwater and anthropogenic influences in the Piracicaba river basin, Southeast Brazil. Atmos Environ, v. 35, p. 4937-4945, 2001. http://dx.doi.org/10.1016/S1352-2310(01)00198-4

LEFSKY, M. A.; HARDING, D. J.; KELLER, M. M.; COHEN, W. B.; CARABAJAL, C. C.; ESPIRITO-SANTO, F. D. B. et al. Estimates of forest canopy height and aboveground biomass using ICESat. Geoph Res Letters, v. 32, p. L22S02, 2005. http://dx.doi.org/10.1029/2005GL023971

LESACK, L. F. W.; MELACK, J. M. The deposition, composition, and potential sources of major ionic solutes in rain of the Central Amazon basin. Water Res Res, v. 27, p. 295377, 1991. http://dx.doi.org/10.1029/91WR01946

LIMA, W. P.; BARBIN, D. Efeito de plantações de Eucaliptus e Pinus sobre a qualidade da água da chuva. IPEF, v. 11, p. 23-35, 1975.

LINDBERG, S. E.; LOVETT, G. M.; RICHTER, D. D.; JOHNSON, D. W. Atmospheric deposition and canopy interactions of major ions in a forest. Sci, v. 231, p. 141-145, 1986. http://dx.doi.org/10.1126/science.231.4734.141

LINDBERG, S. E.; GARTEN JR, T. Sources of sulphur in forest canopy throughfall. Nature, v. 336, p. 148-151, 1988. http://dx.doi.org/10.1038/336148a0

LLOYD, C. R.; MARQUES, A. E. O. Spatial variability of throughfall and stemflow measurements in Amazonian rainforest. Agric For Meteor, v. 42, p. 63-73, 1988. http://dx.doi.org/10.1016/0168-1923(88)90067-6

LOVETT, G. M.; NOLAN, S. S.; DRISCOLL, C. T.; FAHEY, T. J. Factors regulating throughfall flux in a New Hampshire forested landscape. Canadian J For Res, v. 26, p. 2134-2144, 1996. http://dx.doi.org/10.1139/x26-242

MACJANNET, D.; WALLACE, J.; REDDELL, P. Precipitation interception in Australian tropical rainforests: II. Altitudinal gradients of cloud precipitation, stemflow, throughfall and interception. Hydrol Process, v. 21, p. 1703-1718, 2007. http://dx.doi.org/10.1002/hyp.6346

MANOKARAN, N. The nutrient contents of precipitation, throughfall and stemflow in a lowland tropical rain forest in peninsular Malaysia. The Malaysian For, 43:266-289, 1980

MCDOWELL, W. H. Potential effects of acid deposition on tropical terrestrial ecosystem. In: RODHE, H.; HERRERA, R. (Eds.). Acidification in tropical countries. New York: Wiley, 1988. p. 117-139.

MIGLIAVACCA, D.; TEIXEIRA, E. C.; PIRES, M.; FACHEL, J. Study of chemical elements in atmospheric precipitation in South Brazil. Atmos Environ, v. 38, p. 16411656, 2004. http://dx.doi.org/10.1016/j.atmosenv.2003.11.040

NARDOTO, G. B.; BUSTAMANTE, M. M. C. Effects of fire on soil nitrogen dynamics and microbial biomass in savannas of Central Brazil. Pesq Agropec Bras, v. 38, p. 955962, 2003. http://dx.doi.org/10.1590/S0100-204X2003000800008 
OLIVEIRA JUNIOR, R. C.; CORREA, J. R. V. Caracterização dos solos do município de Belterra, Estado do Pará. Belém: Embrapa Amazônia Oriental, 2001. p. 1-39. (Documentos, 88).

PARÁ. Secretaria Estadual de Desenvolvimento Agropecuário e de Pesca - SAGRI. Agricultura. 2011. Available at: <http://www.sagri.pa.gov.br/pagina/agricultura>. Access: 23 April 2013.

PARKER, G. G. Throughfall and stemflow in forest nutrient cycle. Adv Ecol Res, v. 13, p. 55-133, 1983. http://dx.doi.org/10.1016/S0065-2504(08)60108-7

PARROTA, J. A.; FRANCIS, J. K.; ALMEIDA, R. R. Trees of the Tapajós: a photographic field guide. Río Piedras: USDA; Forest Service; International Institute of Tropical Forestry, 1995. 370 p.

PRAKASA RAO, P. S.; MOMIN, G. A.; SAFAI, P. D.; PILlAI, A. G. ; KHEMANI, L. T. Rain water and throughfall chemistry in the silent valley forest in south India. Atmos Environ, v. 29, p. 2025-2029, 1995. http://dx.doi.org/10.1016/1352-2310(94)00294-U

ROCHA, F. R.; SILVA, J. A. F.; LAGO, C. L.; FORNARO, A.; GUTZ, I. G. R. Wet deposition and related atmospheric chemistry in the Sao Paulo metropolis, Brazil, Part 1: major inorganic ions in rainwater as evaluated by capillary electrophoresis with contactless conductivity detection. Atmos, v. 37, p. 105-115, 2003. http://dx.doi.org/10.1016/S1352-2310(02)00722-7

ROELOFS, J. G. M.; KEMPERS, A. J.; HOUDIJK, A. L. F. M.; JANSEN, J. The effects of air-borne ammonium sulphate on Pinus nigra var.maritime in the Netherlands. Plant Soil, v. 84, n. 1, p. 45-56, 1985. http://dx.doi.org/10.1007/BF02197866

SCHLESINGER, W. H. Biogeochemistry: an analysis of global change. New York: Academic Press, 1997. 588 p.

SCHROTH, G.; ELIAS, M. E. A.; UGUEN, K.; SEIXAS, R.; ZECH, W. Nutrient fluxes in rainfall, throughfall and stemflow in tree-based land use systems and spontaneous tree vegetation of central Amazonia. Agric Ecos Env, v. 87, p. 37-49, 2001. http://dx.doi.org/10.1016/S0167-8809(00)00294-2

SETO, S.; OOHARA, M.; IKEDA, Y. Analysis of precipitation chemistry at a rural site in Hiroshima Prefecture, Japan. Atmos Environ, v. 34, p. 621-628, 2000. http://dx.doi.org/10.1016/S1352-2310(99)00166-1

SHEN, W.; REN, H.; JENERETTE, G.D.; HUI, D.; REN, H. Atmospheric deposition and canopy exchange of anions and cations in two plantation forests under acid rain influence. Atmos Envir, v. 64, p. 22-50, 2013.

http://dx.doi.org/10.1016/j.atmosenv.2012.10.015

SOUZA, V. V.; DIAS, H. C. T.; COSTA, A. A.; OLIVEIRA JUNIOR, J. C. Análise da qualidade das águas das precipitações em aberto e efetiva em um fragmento secundário da mata atlântica, no município de Viçosa, MG. R Árvore, v. 31, n. 4, p. 737-743, 2007. http://dx.doi.org/10.1590/S0100-67622007000400019 
STALLARD, R. F.; EDMOND, J. M. Geochemistry of the Amazon. 1. Precipitation chemistry and the marine contribution to the dissolved load at the time of peak discharge. J Geophys Res, v. 86, p. 1981. http://dx.doi.org/10.1029/JC086iC10p09844

STEINHARDT, V.; FASSBENDER, H. W. Características y composición química de las lluvias de los Andes Occidentales de Venezuela. Turrialba, v. 29, p. 175-82, 1979.

STOORVOGEL, J. J.; VAN BREEMEN, N.; JANSEN, B. H. The nutrient input by Harmattan dust to a forest ecosystem in Côte d' Ivoire, Africa. Biogeochemistry, v. 37 , p. 145-157, 1997. http://dx.doi.org/10.1023/A:1005734225727

SVERDRUP, H.; DE VRIES, W.; HENRIKSEN, A. Mapping critical loads. Report 1990:14. Copenhagen: Nordic council of Minister, 1990.

TANNER, P. A.; FAI, T. W. Small scale horizontal variations in ionic concentrations of bulk deposition from Hong Kong. Water Air Soil Pollut, v. 122, p. 433-448, 2000. http://dx.doi.org/10.1023/A:1005245222016

TANNER, P. A.; WONG, A. Y. S. Soluble trace metals and major ionic species in the bulk deposition and atmosphere of Hong Kong. Water Air Soil Pollut, v. 122, p. 261-279, 2000. http://dx.doi.org/10.1023/A:1005232313641

TOBÓN MARIN, C.; BOUTEN, W.; SEVINK, J. Gross rainfall and its partitioning into throughfall, stemflow and evaporation of intercepted water in four forest ecosystems in western Amazonia. J Hydrol, v. 237, p. 40-57, 2000. http://dx.doi.org/10.1016/S00221694(00)00301-2

TOPCU, S.; INCECIK, S.; ATIMTAY, A. T. Chemical composition of rainwater at EMEP station in Ankara, Turkey. Atmos Res, v. 65, p. 77-92, 2002. http://dx.doi.org/10.1016/S0169-8095(02)00072-8

TRESMONDI, A. C. L.; TOMAZ, E.; KRUSCHE, A. V. Deposições úmidas em Paulínia-SP e região. In: CONGRESSO INTERAMERICANO DE QUALIDADE DO AR - AIDIS, 3., 2003, Canoas, RS. Proceedings... 2003. Canoas: AIDIS, 2003. p. 45-49.

ULRICH, B. Interaction of forest canopies with atmospheric constituents: SO2, alkali and Herat alkali cations and chloride. In: ULRICH, B.; PANKKRATH, J. (Eds.). Effects of accumulation of air pollutants in forest ecosystems. Dordrecht: Reídle, 1983. p. 3335

VENTURIERI, A.; COELHO, A. S.; THALES, M. C.; BACELAR, M. D. R. Análise da expansão da agricultura de grãos na região de Santarém e Belterra, Oeste do estado do Pará. In: SIMPÓSIO BRASILEIRO DE SENSORIAMENTO REMOTO, 13., 2007, Florianópolis. Artigos... São José dos Campos: INPE, 2007. p. 7003-7010. Available in: <http://marte.dpi.inpe.br/col/dpi.inpe.br/sbsr@80/2006/11.16.02.21/doc/70037010.pdf>. Access: 17 January 2015.

VERNIMMEN, R. R. E.; BRUIJNZEEL, L. A.; ROMDONI, A.; PROCTOR, J. Rainfall interception in three contrasting lowland forest types in Central Kalimantan, Indonesia. J Hydrol, v. 340, n. 3-4, p. 217-232, 2007. http://dx.doi.org/10.1016/j.jhydrol.2007.04.009 
WHITMORE, T. C. Tropical rain forest of the Ear East. Oxford: Claredon Press, 1975.

ZENG, G. M.; ZHANG, G.; HUANG, G. H.; JIANG, Y. M.; LIU, H. L. Exchange of $\mathrm{Ca}^{2+}$, $\mathrm{Mg}^{2+}$ and $\mathrm{K}^{+}$and uptake of $\mathrm{H}^{+}, \mathrm{NH}_{4}{ }^{+}$for the subtropical forest canopies influenced by acid rain in Shaoshan forest located in Central South China. Plant Sci, v. 168, p. 259266, 2005. http://dx.doi.org/10.1016/j.plantsci.2004.08.004 